\title{
Description of Leucocyte Differential Count in Pregnant Women with COVID-19
}

Gambaran Hitung Jenis Leukosit pada Wanita Hamil dengan COVID-19

\author{
Nabila Alifiah, ${ }^{1}$ Siemona L. E. Berhimpon, ${ }^{2}$ Glady I. Rambert ${ }^{2}$
}

\author{
${ }^{1}$ Program Studi Pendidikan Dokter Fakultas Kedokteran Universitas Sam Ratulangi Manado, \\ Indonesia \\ ${ }^{2}$ Bagian Patologi Klinik Fakultas Kedokteran Universitas Sam Ratulangi, Manado, Indonesia \\ Email: alifiyahnbl1212@gmail.com \\ Received: January 13, 2021; Accepted: February 14, 2022; Published on line: February 16, 2022
}

\begin{abstract}
Coronavirus disease 2019 (COVID-19) caused by severe acute respiratory syndrome coronavirus 2 (SARS-CoV-2) has a high rate of transmission. Pregnant women are at high risk of infection due to the changes in their physiological and immune systems. This study aimed to determine the leukocyte differential count leukocyte in pregnant women with COVID-19. This was a descriptive study with a retrospective approach, using secondary data of the patients' medical records during the periode of July-August 2021 at Prof. Dr. R. D. Kandou Hospital, Manado. The results showed that of 57 pregnant women with COVID-19, 92\% had normal leukocyte differential count, $100 \%$ had normal basophil and eosinophil counts, $12 \%$ had neutrophilia, 23\% had lymphopenia, and 95\% had normal monocyte counts. In conclusion, in pregnant women with COVID-19 at Prof. Dr. R. D. Kandou Hospital, the most common abnormalities in leucocyte differential count are lymphopenia and neutrophilia
\end{abstract}

Keywords: pregnant women; COVID-19; leukocyte differential count

\begin{abstract}
Abstrak: Coronavirus disease 2019 (COVID-19) yang disebabkan oleh severe acute respiratory syndrome coronavirus 2 (SARS-CoV-2) mempunyai tingkat penularan yang sangat tinggi. Wanita hamil berisiko tinggi terinfeksi COVID-19 karena adanya perubahan fisiologik dan sistem imun. Penelitian ini bertujuan untuk mengetahui gambaran hitung jenis leukosit pada wanita hamil dengan COVID-19. Jenis penelitian yang digunakan ialah deskriptif retrospektif dengan menggunakan data sekunder rekam medik periode Juli-Agustus 2021 di RSUP Prof. Dr. R. D. Kandou. Hasil penelitian memperlihatkan bahwa dari 57 wanita hamil terkonfirmasi COVID-19, terdapat $92 \%$ dengan nilai hitung leukosit normal, $12 \%$ mengalami neutrofilia, $23 \%$ mengalami limfopenia, 95\% memiliki nilai hitung monosit normal, dan 100\% memiliki nilai hitung basofil dan eosinofil normal. Simpulan penelitian ini ialah kelainan hitung jenis leukosit yang paling sering ditemukan pada wanita hamil terkonfirmasi COVID-19 di RSUP Prof. Dr. R. D. Kandou ialah neutrofilia dan limfopenia.
\end{abstract}

Kata kunci: wanita hamil; COVID-19; hitung jenis leukosit

\section{PENDAHULUAN}

Coronavirus disease 2019 (COVID-19) pertama kali dilaporkan di Wuhan, Provinsi Hubei, China pada Desember 2019. ${ }^{1}$ Virus penyebab COVID-19 ialah severe acute respiratory syndrome coronavirus 2 (SARS$\mathrm{CoV}-2$ ) yang sangat tinggi tingkat penularan- nya antar manusia. ${ }^{2}$

World Health Organization (WHO) mendeklarasikan COVID-19 sebagai pandemi global pada tanggal 11 Maret 2020. Hingga Agustus 2021 di Indonesia sebanyak 3.908.247 orang dilaporkan terkonfirmasi positif COVID-19, dengan angka kematian 
121.141 orang dan 3.443.903 pasien sembuh. $^{3}$ COVID-19 merupakan gangguan saluran pernapasan akut dengan $80 \%$ asimtomatis dan gejala ringan (mild); $15 \%$ membutuhkan oksigen (severe); dan 5\% membutuhkan ventilator (critically ill). ${ }^{4}$ Pada pasien COVID-19 dapat ditemukan kelainan hematologik seperti leukositosis, limfopenia dan neutrofilia yang dapat menjadi parameter dalam menilai keparahan infeksi SARS-CoV-2. ${ }^{5}$

Secara umum kehamilan dianggap sebagai keadaan berisiko tinggi terkena infeksi. Penyebabnya yaitu terjadi perubahan fisiologik tubuh yang membuat sistem imun pada wanita hamil menurun. ${ }^{6}$ Secara fisiologik wanita hamil pada trimester pertama akan mengalami kenaikan leukosit dan meningkat secara gradual seiring pertambahan usia kehamilan. $^{7}$

Meskipun wanita hamil berisiko tinggi terinfeksi, data dari Amerika Serikat menunjukkan bahwa kematian wanita hamil akibat COVID-19 pada gelombang pertama pandemi (Januari hingga Juni 2020) tergolong rendah $(0,9 \%){ }^{8}$ Sejak gelombang kedua pandemi (September 2020) sejumlah negara seperti Spanyol dan Inggris menunjukkan tingkat keparahan penyakit pada wanita hamil dengan COVID-19 yang mengalami dampak lebih buruk. ${ }^{9,10}$ Berdasarkan data Perkumpulan Obstetri dan Ginekologi Indonesia (POGI), hingga April 2021 kematian wanita hamil karena komplikasi COVID-19 sebanyak $3 \% .^{11}$

Pada gelombang kedua pandemi terjadi kenaikan angka kematian wanita hamil dengan COVID-19 disertai gambaran laboratorium pasien COVID-19 yang menunjukkan perubahan jumlah leukosit yaitu leukositosis, neutrofilia, dan limfopenia. Bertolak dari latar belakang yang telah dipaparkan maka penulis terdorong untuk mengetahui gambaran hitung jenis leukosit pada wanita hamil dengan COVID-19 menggunakan data rekam medik bulan JuliAgustus 2021 di RSUP Prof. Dr. R. D. Kandou. Diharapkan bahwa hasil penelitian ini dapat memperkaya data penelitian mengenai COVID-19 yang masih relatif baru.

\section{METODE PENELITIAN}

Penelitian ini dilakukan di Bagian Rekam Medik RSUP Prof. Dr. R. D. Kandou Manado pada bulan Oktober-Desember 2021 dengan menggunakan data sekunder berupa catatan rekam medik pasien. Jenis penelitian ialah deskriptif retrospektif. Untuk menentukan sampel penelitian digunakan kriteria inklusi yaitu wanita hamil positif COVID-19, dirawat di RSUP Prof. Dr. R. D. Kandou Manado, dengan data yang tercatat dalam rekam medik bulan JuliAgustus 2021. Kriteria eksklusi ialah pasien dengan data rekam medik tidak lengkap.

\section{HASIL PENELITIAN}

Pada penelitian ini didapatkan 57 sampel wanita hamil dengan COVID-19 selang waktu bulan Juli-Agustus 2021 yang memenuhi kriteria inklusi. Data karakteristik dan gambaran hitung jenis leukosit sampel diolah dan disajikan dalam bentuk tabel.

Tabel 1 memperlihatkan distribusi usia wanita hamil dengan COVID-19. Kasus terbanyak ialah kelompok usia 21-25 tahun sebanyak 15 orang (26\%). Kasus paling sedikit pada kelompok usia 16-20 sebanyak 5 orang (9\%). Usia termuda yang didapatkan ialah 16 tahun dan usia tertua ialah 43 tahun.

Tabel 1. Distribusi usia wanita hamil dengan COVID-19

\begin{tabular}{ccc}
\hline $\begin{array}{c}\text { Kelompok } \\
\text { usia (tahun) }\end{array}$ & $\begin{array}{c}\text { Frekuensi } \\
(\mathbf{n})\end{array}$ & $\begin{array}{c}\text { Persentase } \\
(\boldsymbol{\%})\end{array}$ \\
\hline $16-20$ & 5 & 9 \\
$21-25$ & 15 & 26 \\
$26-30$ & 13 & 23 \\
$31-35$ & 14 & 25 \\
$>35$ & 10 & 17 \\
Total & 57 & 100 \\
\hline
\end{tabular}

Tabel 2 memperlihatkan distribusi berdasarkan usia kehamilan. Kasus terbanyak ialah wanita hamil pada trimester 3 yaitu 55 orang (97\%). Tidak didapatkan wanita hamil trimester I.

Tabel 3 memperihatkan jumlah leukosit pada wanita hamil dengan COVID-19. Sebagian besar (92\%) memperlihatkan nilai normal. 
Tabel 2. Distribusi usia kehamilan wanita hamil dengan COVID-19

\begin{tabular}{ccc}
\hline $\begin{array}{c}\text { Usia } \\
\text { kehamilan }\end{array}$ & Frekuensi & $\begin{array}{c}\text { Persentase } \\
(\boldsymbol{\%})\end{array}$ \\
\hline Trimester 1 & 0 & 0 \\
Trimester 2 & 2 & 3 \\
Trimester 3 & 55 & 97 \\
Total & 57 & 100 \\
\hline
\end{tabular}

Tabel 3. Jumlah leukosit pada wanita hamil dengan COVID-19

\begin{tabular}{ccc}
\hline Leukosit & Frekuensi & $\begin{array}{c}\text { Persentase } \\
(\%)\end{array}$ \\
\hline Normal & 52 & 92 \\
$\left(5,9-16,9 \times 10^{3} / \mu \mathrm{L}\right)$ & & 5 \\
Meningkat & 3 & \\
$\left(>16,9 \times 10^{3} / \mu \mathrm{L}\right)$ & & 3 \\
Menurun & 2 & 100 \\
$\left(<5,9 \times 10^{3} / \mu \mathrm{L}\right)$ & & \\
Total & 57 & \\
\hline
\end{tabular}

Tabel 4 memperlihatkan gambaran hitung jenis leukosit pada wanita hamil dengan COVID-19. Jumlah basofil dan eosinofil pada $100 \%$ pasien dalam batas normal. Neutrofil pada tujuh pasien $(12 \%)$ mengalami kenaikan. Limfosit pada 13 pasien $(23 \%)$ mengalami penurunan dan monosit pada 54 pasien (95\%) dalam kategori normal.

\section{BAHASAN}

Pada penelitian ini didapatkan 57 wanita hamil yang memenuhi kriteria inklusi. Berdasarkan distribusi usia wanita hamil, yang terbanyak ialah kelompok usia 21-25 tahun (26\%) sedangkan paling sedikit di kelompok usia 16-20 tahun (9\%). Hal ini dapat dikarenakan usia yang dianggap aman untuk mengalami kehamilan dan persalinan ialah usia 20-35 tahun. ${ }^{12}$ Faktor pendidikan dan pengetahuan juga berpengaruh dalam seseorang mempertimbangkan suatu kehamilan. ${ }^{13}$ Tabel 2 memperlihatkan bahwa usia kehamilan pasien paling banyak pada trimester 3 (97\%). Hal ini sejalan dengan studi dari Chinese Clinical Guidance for COVID-19 Pneumonia Diagnosis and Treatment pada 118 kasus COVID-19; 75 (64\%) di antaranya ialah wanita hamil trimester $3 .{ }^{14}$ Kunjungan wanita hamil untuk memeriksakan kandungan ialah sebulan sekali pada enam bulan pertama, dan setelah memasuki trimester 3 kunjungan wanita hamil menjadi dua minggu sekali. Hal ini dapat meningkatkan risiko penularan COVID-19 pada wanita hamil. ${ }^{15}$

Hasil penelitian mendapatkan jumlah leukosit pada $92 \%$ wanita hamil berada dalam rentang nilai normal, sedangkan pada tiga orang lainnya (5\%) jumlah leukosit meningkat. Hal ini tidak sejalan dengan review data oleh Dasraath et $\mathrm{al}^{16}$ yang mendapatkan leukositosis pada $38 \%$ wanita hamil dengan COVID-19. Sebuah studi retrospektif oleh Liu et al ${ }^{17}$ melaporkan bahwa pada 16 wanita hamil terkonfirmasi SARS-CoV-2 melalui pemeriksaan laboratorium, didapatkan delapan di antaranya mengalami leukositosis (50\%).

Tabel 4. Gambaran hitung jenis leukosit pada wanita hamil dengan COVID-19

\begin{tabular}{ccccccc}
\hline Jenis leukosit & \multicolumn{2}{c}{ Normal } & \multicolumn{2}{c}{ Meningkat } & \multicolumn{2}{c}{ Menurun } \\
& $\mathrm{n}$ & $\%$ & $\mathrm{n}$ & $\%$ & $\mathrm{n}$ & $\%$ \\
\hline Basofil & 57 & 100 & 0 & 0 & 0 & 0 \\
$\left(0-0,1 \times 10^{3} / \mu \mathrm{L}\right)$ & & & & & & \\
$\begin{array}{c}\text { Eosinofil } \\
\left(0-0,6 \times 10^{3} / \mu \mathrm{L}\right)\end{array}$ & 57 & 100 & 0 & 0 & 0 & 0 \\
$\begin{array}{c}\text { Neutrofil } \\
\left(3,9-13,1 \times 10^{3} / \mu \mathrm{L}\right) \\
\quad \text { Limfosit }\end{array}$ & 49 & 86 & 7 & 12 & 1 & 2 \\
$\left(1,0-3,6 \times 10^{3} / \mu \mathrm{L}\right)$ \\
$\begin{array}{c}\text { Monosit } \\
\left(0,1-1,4 \times 10^{3} / \mu \mathrm{L}\right)\end{array}$ & 54 & 75 & 1 & 2 & 13 & 23 \\
\hline
\end{tabular}


Selama kehamilan leukosit akan meningkat secara fisiologik, namun leukositosis juga dapat menjadi indikasi adanya infeksi/sepsis. ${ }^{7}$ Hasil laboratorium yang sering ditemukan pada pasien COVID-19 ialah jumlah total leukosit normal atau sedikit meningkat yang disertai limfopenia. ${ }^{18}$

Hasil penelitian ini mendapatkan nilai basofil pada $100 \%$ wanita hamil termasuk dalam kategori normal. Hal ini sejalan dengan studi oleh Sun et al $^{19}$ pada 57 pasien COVID-19, yang mendapatkan nilai basofil pada semua pasien dalam batas normal. Basofil yang disebut juga sel mast dapat menyekresi heparin dan histamin pada adanya reaksi alergik. Nilai basofil tidak berubah secara bermakna selama kehamilan. ${ }^{20}$

Nilai eosinofil pada penelitian ini didapatkan pada $100 \%$ wanita hamil dalam kategori normal. Hal ini sejalan dengan studi yang dilakukan oleh Sasson et $\mathrm{al}^{21}$ terhadap 11 wanita hamil yang menunjukkan nilai eosinofil dalam batas normal. Berbeda halnya dengan hasil penelitian oleh Li et $\mathrm{al}^{22}$ yang membandingkan wanita hamil normal dengan wanita hamil terkonfirmasi COVID19 dan melaporkan adanya penurunan nilai eosinofil secara bermakna. Pada pasien COVID-19 dapat ditemukan eosinopenia dikarenakan eosinofil dapat berperan sebagai antivirus. Selain itu, eosinofil dapat mengeluarkan oksida nitrat yang kemudian menginduksi aktivasi sel T CD8+. ${ }^{23}$ Keadaan fase akut infeksi paru yang disebabkan oleh virus SARS-CoV-2 mengakibatkan eosinofil menumpuk pada jaringan terinfeksi untuk melawan infeksi virus, yang menyebabkan penurunan eosinofil dalam darah. ${ }^{24}$

Jumlah neutrofil menunjukkan kenaikan pada tujuh wanita hamil (12\%). Hal ini sejalan dengan multidisciplinary review oleh Narang et $\mathrm{al}^{25}$ yang mendapatkan delapan dari 93 wanita hamil dengan COVID-19 mengalami neutrofilia $(8,6 \%)$. Sebuah studi retrospektif oleh $\mathrm{Yu}$ et $\mathrm{al}^{26}$ terhadap 7 wanita hamil dengan COVID-19 di Wuhan melaporkan terdapatnya neutrofilia pada lima pasien $(71 \%)$. Neutrofilia dapat ditemukan pada infeksi, pendarahan, melahirkan, dan menstruasi. ${ }^{27}$ Neutrofilia pada wanita hamil dapat bersifat fisiologik yang merupakan bentuk imunosupresi dan imunomodulasi dari fetus. ${ }^{28}$ Neutrofilia juga sering dijumpai pada pasien dengan infeksi SARS-CoV-2 yang berat. ${ }^{23}$

Pada hasil pemeriksaan limfosit didapatkan 13 wanita hamil mengalami limfopenia (23\%). Ryan et $\mathrm{al}^{29}$ membandingkan beberapa studi penelitian dan mendapatkan limfopenia sebanyak 22\%, 44\%, dan $14 \%$ pada wanita hamil dengan COVID-19. ${ }^{16,29,30}$ Pada infeksi SARS-CoV-2 terjadi respons inflamasi berlebihan, yang menyebabkan terjadinya migrasi limfosit dari dalam darah ke paru sehingga terjadi defisiensi limfosit dalam darah atau limfopenia. ${ }^{23}$

Hasil penelitian ini mendapatkan jumlah monosit normal pada $54(95 \%)$ wanita hamil, dua pasien dengan jumlah monosit meningkat (3\%), dan satu pasien dengan jumlah monosit menurun (2\%). Studi yang dilakukan oleh Sasson et $\mathrm{al}^{21}$ terhadap 11 wanita hamil mendapatkan hasil monosit dalam jumlah normal. Pada wanita hamil monosit akan meningkat pada trimester pertama, kemudian menurun seiring bertambahnya usia kehamilan. ${ }^{31}$

\section{SIMPULAN}

Kelainan tersering pada gambaran hitung jenis leukosit wanita hamil dengan COVID-19 di RSUP Prof. Dr. R. D. Kandou Manado periode Juli-Agustus 2021 ialah limfopenia dan neutrofilia.

\section{Konflik Kepentingan}

Penulis menyatakan tidak terdapat konflik kepentingan dalam studi ini.

\section{DAFTAR PUSTAKA}

1. Huang C, Wang Y, Li X, Ren L, Zhao J, Hu Y, et al. Clinical features of patients infected with 2019 novel coronavirus in Wuhan, China. Lancet (London, England). 2020;395(10223):497-506.

2. Yan Y, Shin WI, Pang YX, Meng Y, Lai J, You $\mathrm{C}$, et al. The first 75 days of novel coronavirus (SARS-CoV-2) outbreak: Recent advances, prevention, and treatment. Int J Environ Res Public Health. 2020;17(7):2323.

3. Indonesia: WHO Coronavirus Disease 
(COVID-19) Dashboard With Vaccination Data | [Internet]. [cited 2021 Aug 23].

4. Rohmah MK, Rahman Nurdianto A. Perspective of molecular immune response of SARS-COV-2 infection. J Teknol Lab. 2020;9(1):58-66.

5. Mus R, Thaslifa T, Abbas M, Sunaidi Y. Studi literatur: tinjauan pemeriksaan laboratorium pada pasien COVID-19. J Kesehat Vokasional. 2021;5(4):242.

6. Akbar A. Gejala klinis infeksi virus corona 2019 (Covid-19) pada wanita hamil. J Implementa Husada. 2020;1(2):172-80.

7. Pughikumo C, Pughikumo D, Omunakwe H. White blood cell counts in pregnant women in Port Harcourt, Nigeria. IOSR J Dent Med Sci Ver II [Internet]. 2015;14(3):2279-861. Available from: www.iosrjournals.org

8. Zambrano LD, Ellington S, Strid P, Galang RR, Oduyebo T, Tong VT, et al. Update: characteristics of symptomatic women of reproductive age with laboratoryconfirmed SARS-CoV-2 infection by pregnancy status - United States, January 22-October 3, 2020. MMWR Morb Mortal Wkly Rep. 2020;69(44): 1641-7.

9. Kadiwar S, Smith JJ, Ledot S, Johnson M, Bianchi P, Singh N, et al. Were pregnant women more affected by COVID-19 in the second wave of the pandemic? Lancet [Internet]. 2021;397(10284): 1539-40.

10. Iftimie S, Lopez-Azcona AF, Vallverdu I, Hernandez-Flix S, De Febrer G, Parra S, et al. First and second waves of coronavirus disease-19: A comparative study in hospitalized patients in Reus, Spain. PLoS One. 2021;16(3):1-13.

11. POGI. Revisi-Rekomendasi-POGI-utkBumil-dengan-Covid-19-.pdf. 2020.

12. Sulistyawati A. Asuhan Kebidanan Pada Masa Hamil dan Tumbuh Kembang anak. Jakarta: Salemba Medika; 2015 [cited 2021 Dec 28];264.

13. Kurniawati A, Nurdianti D. Karakteristik ibu hamil dengan pengethuan dan sikap dalam mengenal tanda bahaya kehamilan. J Bimtas [Internet]. 2018;2(1): 32-41.

14. Chen L, Li Q, Zheng D, Jiang H, Wei Y, Zou $\mathrm{L}$, et al. Clinical characteristics of pregnant women with Covid-19 in
Wuhan, China. N Engl J Med. 2020; 382(25):e100.

15. Aisyah RD, Rusmariana A, Mujiati D. Frekuensi kunjungan ANC (antenatal care) pada ibu hamil trimester III. J Ilm Kesehat. 2015;VIII(2):1-5.

16. Dashraath P, Wong JLJ, Lim MXK, Lim LM, Li S, Biswas A, Choolani M, Mattar C SL. Special report and pregnancy. Am J Obs Gynecol. 2020;222(6):521-31.

17. Liu H, Liu F, Li J, Zhang T, Wang D, Lan W. Clinical and CT imaging features of the COVID-19 pneumonia: focus on pregnant women and children. $\mathrm{J}$ Infect [Internet]. 2020;80(5):e7-13.

18. Syeda S, Baptiste C, Breslin N, GyamfiBannerman C, Miller R. The clinical course of COVID in pregnancy. Semin Perinatol [Internet]. 2020;44(7):151284.

19. Sun D-w, Zhang D, Tian R-h, Li Y, Wang Y$\mathrm{s}$, Cao J, et al. The underlying changes and predicting role of peripheral blood inflammatory cells in severe COVID-19 patients: a sentinel? Clin Chim Acta. 2020;508(May):122-9.

20. Morton A. Hematological normal ranges in pregnancy. Contin Textb Women's Med Ser - Obstet Modul. 2021;1-13.

21. Mohr-Sasson A, Chayo J, Bart Y, Meyer R, Sivan E, Mazaki-Tovi S, et al. Laboratory characteristics of pregnant compared to non-pregnant women infected with SARS-CoV-2. Arch Gynecol Obstet [Internet]. 2020;302(3):629-34.

22. Li N, Han L, Peng M, Lv Y, Ouyang Y, Liu K, et al. Maternal and neonatal outcomes of pregnant women with coronavirus disease 2019 (COVID-19) pneumonia: a case-control study. Clin Infect Dis an Off Publ Infect Dis Soc Am. 2020; 71(16):2035-41.

23. Rosyanti L, Hadi I. Respon imunitas dan badai sitokin severe acute respiratory syndrome coronavirus 2 literatur review. J Kesehat Madani Med. 2020;11(02): 176-201.

24. Sun S, Cai X, Wang H, He G, Lin Y, Lu B, et al. Abnormalities of peripheral blood system in patients with COVID-19 in Wenzhou, China. Clin Chim Acta. 2020;507:174-80.

25. Narang K, Enninga EAL, Gunaratne MDSK, Ibirogba ER, Trad ATA, Elrefaei A, et al. SARS-CoV-2 Infection and COVID19 during pregnancy: a multi-discipli- 
nary review. Mayo Clin Proc [Internet]. 2020;95(8):1750-65.

26. Yu N, Li W, Kang Q, Xiong Z, Wang S, Lin $\mathrm{X}$, et al. Clinical features and obstetric and neonatal outcomes of pregnant patients with COVID-19 in Wuhan, China: a retrospective, single-centre, descriptive study. Lancet Infect Dis [Internet]. 2020;20(5):559-64.

27. Kementerian Kesehatan RI. Pedoman Interpretasi Data Klinik. Kementerian Kesehatan Republik Indonesia. 2011; (January):1-83.

28. Kaur S, Kha n S, Nigam A. Hematological profile and pregnancy: a review. Int $\mathrm{J}$ Adv Med. 2014;1(2):1.
29. Ryan GA, Purandare NC, McAuliffe FM, Hod $\mathrm{M}$, Purandare $\mathrm{CN}$. Clinical update on COVID-19 in pregnancy: a review article. J Obstet Gynaecol Res. 2020; 46(8):1235-45.

30. Elshafeey F, Magdi R, Hindi N, Elshebiny M, Farrag N, Mahdy S, et al. A syste-matic scoping review of COVID-19 during pregnancy and childbirth. Int J Gynaecol Obstet. 2020;150(1):47-52.

31. Edelstam G, Löwbeer C, Kral G, Gustafsson SA, Venge P. New reference values for routine blood samples and human neutrophilic lipocalin during third-trimester pregnancy. Scand J Clin Lab Invest. 2001;61(8):583-92. 